\title{
The Impact of Ingredient Brand Awareness on Host Brand Attitude: The Moderating Role of Regulatory Focus
}

\author{
Darkhantuya Sergelen \\ Chonbuk National University \\ Urandelger Gantulga \\ National University of Mongolia \\ urandelger@num.edu.mn
}

\begin{abstract}
Companies are attempting to increase their competitiveness using a number of strategies. The brand alliance strategy, which is one of the most commonly employed methods, has a favorable impact on the company's market share due to the strong recognition of a well-known brand in the early stage of market entrance. The main purpose of this study is to examine the effect of ingredient brand awareness on the consumers' evaluation of host brands. With the purpose of it, the study examined the changes of attitudes toward the host brands by ingredient's brand awareness (high/low).We also tested the moderating roles of consumers' regulatory focus (promotion/prevention focus) on the relationship between ingredient brand awareness and host brands attitude. The results of this study are summarized as follow. First, consumers tend to be more favorable toward host brand products when brand awareness was higher than lower. Second, the effect of consumers' regulatory focus (promotion focus/prevention focus) was found to be positive and significant effect between ingredient brand awareness and host brand attitude. Based on the findings, the theoretical and managerial implication are discussed.
\end{abstract}

Keywords:Ingredient Brand Awareness, Psychological Distance Cue, Consumer Regulatory Focus, Brand Attitude, South Korea.

DOI: $10.7176 / \mathrm{EJBM} / 13-20-04$

Publication date:October $31^{\text {st }} 2021$

\section{INTRODUCTION}

A variety of brand alliance strategies are being employed to boost the company's profitability. Brand alliance strategy takes the form of co-branding, which combines two or more existing brands equally. Brand alliances, ingredient branding, and collaborative promotions are all examples of co-branding. According to the research studies, there are two types of co-branding strategies: Symbolic co-branding and ingredient branding. The first technique entails linking a second brand with the host brand in order to provide symbolic additional attributes (Cegarra and Michel, 2000). In the second, important characteristics of one brand are used as ingredients in another brand (Desai and Keller, 2002). The host brand in a co-branding is the "brand that originated from the product category in which the co-branded product is launched" (Cegarra and Michel, 2000), whereas the ingredient brand is the one that manufactures the ingredient or has the know-how to incorporate it into the final product.

Nowadays, companies are paying greater attention to ingredient branding, and several research are being studied on the both positive and negative impacts of ingredient branding. Existing literature investigates the factors that affect the ingredient brands. However, there are limited research available on how ingredient brands influence the host brands. Park et al (1996) demonstrate that host brands are evaluated more favorably when they are associated with a high awareness ingredient brand. Janiszewski and van Ossalaer (2000) find that ingredient brands will be evaluated more favorably only when the co-branding performs more favorably than expected. Therefore, the impact of ingredient branding on attitude toward host brand is not clear.

The ingredient branding has different influences on consumer evaluation. If the ingredient brand has a high equity, it has the effect of relieving the negative perception produced by the host brand with a low equity (Washburn, Brian, and Randi, 2000). Although, ingredient brands has been shown to have a positive influence on moderate quality rather than high quality brands (McCarthy \& Norris, 1999).

Therefore, in this study, we would like to investigate at how consumers' perceptions of host brand products are influenced by their awareness of ingredient brands from a variety of perspectives. The main objective of the current research is to answer the following an research question: How does this behavior differ based on ingredient brands awareness (e.g., higher vs. lower) and host brand attitude across regulatory focus (e.g., promotion vs. prevention-focus)?

More specifically, how consumers' (high/low) awareness of ingredient brands affects their attitudes toward host brand products, and how these factors changed by consumers' psychological characteristics (the regulatory focus). The results of this study contribute to the effective marketing segmentation strategy and the body of literature on consumer behavior towards ingredient branding. 


\section{THEORETICAL BACKGROUND AND HYPOTHESES DEVELOPMENT}

\subsection{Ingredient Brand Awareness}

A brand is a combination of names and symbols used to identify a specific company's products or services to differentiate it from competitors (Kwang-Ho Ahn, 2012). Therefore, companies are making great efforts to differentiate their brands, however as consumer standards become more complex. If companies can successfully build an ingredient brand in order to give differentiated value to add end products, they can gain market share.

Brand awareness is an important factor to consider in consumer behavior. It relates to customer's ability to recall or recognize a brand, as well as whether or not they are aware of it (Keller, 2008). Consumers with high brand awareness have favorable attitudes toward unfamiliar products. On the other hand, consumers with low brand awareness have unfavorable attitudes toward unfamiliar products because of unfamiliar with the brand names, further information on this product category is required for evaluation.

Ingredient branding is a marketing approach in which a business component is branded as a distinct entity. In order to make a better product, the ingredients brands were developed and branded separately from the main business. This contributes to the parent company's value and makes its product appear superior to its competitors.

In another word, the ingredient brand is a component of the product manufactured by the host brand. They also discovered that co-branded ingredients lead to more favorable product assessments. Furthermore, by enhancing customer knowledge of its own brand, the ingredient brand may increase its bargaining leverage with the host brand.

Therefore, it is becoming more popular among marketers (Simonin and Ruth 1998, Desai \& Keller, 2002). In ingredient branding there is no need for companies to develop a new product, nor is there a need to heavily invest in efforts to bring the organizations together when entering new markets (Blackett and Boad 1999).

Ingredient branding strategy refers to the branding of product ingredients (materials, components, parts, etc.) so that when consumers purchase the end product, the ingredient brand becomes an important decision-making factor in purchasing. When companies implement their ingredient brand strategy well, consumers have the following advantages in purchasing products. First, it can simplify the process of information about product ingredients. In other words, it will have a positive effect on consumers' attitudes towards the host brand products because the consumer's judgment is simplified to the brand, reducing the purchase process and cost. Second, since the ingredient brand acts as a powerful differentiation tool, it will reduce the difficulty of selection in the consumer decision-making process.

However, not all ingredient branding can be successful. In general, major brands tend to seek alliances with high-recognition brands similar to themselves in order to avoid negative associations that may arise from alliances with unknown brands when selecting ingredient brands (Rao \& Ruekert, 1994). Therefore, most of the brands are affiliated with well-known brands, and such alliances can deliver positive information about product quality to consumers, which will ultimately have a positive effect on consumers' product evaluations. From the perspective of enhancing consumer awareness, affiliation with a high-awareness ingredient brand has a positive effect on consumer evaluation of lower quality brands (Levin, Davis \& Levin, 1996).

\subsection{Promotion-focus VS Prevention-focus in Regulatory Focus Theory}

Regulatory focus theory is a goal-oriented theory that considers a person's perceptions during the decision-making process (Higgins, 1998). It investigates the link between an individual's motivation and how they attain their goal in general.

Although Crowe \& Higgins (1997) proposed the 'self-regulation focus theory' that people self-regulate pleasure-seeking and pain-avoidance through certain strategies. In other words, people use either an promotion focus or a preventive focus to control their motivation.

People with an promotion focus tend to be interested in, expect, and aspire to positive outcomes in goal pursuit. Whereas, people with a prevention focus tend to focus on negative outcomes in goal pursuit, seek stability and remove failure factors (Jun-Sang Yeo, 2006). In addition, people with the promotion focus show positive emotions such as happiness when they reach a positive state such as achieving a goal, whereas those with a prevention focus experience positive emotions like stability when no negative outcomes occur (Dahee Song, 2017).

Furthermore, conspicuous and emotional value had a greater influence on luxury brand attitudes for promotion-focused consumers, whereas prevention-focused consumers placed more importance on quality and economic values (Suh, 2011). People with an promotion focus tend to focus on solving problems quickly rather than accuracy, whereas people with a preventive focus tend to perform tasks more accurately, even if they are performed slowly (Förster, Higgins \& Bianco, 2003).

Based on previous studies, promotion-focused consumers tend to show an positive attitude toward new brands, whereas preventive-focused consumers always have a passive attitude and tend to avoid risks.

Therefore, prevention-focused consumers prefer the compromise option, whereas promotion-focused consumers are more inclined to try new things and prefer the extreme option that can maximize potential benefits.

Consumers with a prevention focus have a stronger tendency to maintain the existing alternatives. Consumers 
with a promotion focus have higher purchase intentions when risks are implicitly presented rather than explicitly presented (Chernev, 2004).

\subsection{Brand Attitude}

Brand attitude is the foundation of consumer actions (Keller 1993), and it is a constant favorable or unfavorable reaction to a specific product and service (Fishbein \& Ajzein 1975). Brand attitude is defined by Kotler et al. 1999 as a favorable or unfavorable emotional feeling, and behavioral tendency that an individual holds. According to Keller (2002), brand attitude is an overall evaluation of customers on a product with a brand. Wilkie (1986) and Keller (1993) indicated that a consumer's attitude towards an brand referred to the consumer's overall evaluation of that brand, and forms the basis for consumer behavior towards that brand. In most cases, the ingredient brand alters an existing attribute in the host category, usually to aid the host brand in improving perceptions of performance on that attribute.

\section{HYPOTHESES DEVELOPMENT}

\subsection{Effect of ingredient brand awareness on host brand attitude}

Brand awareness refers to the strength of attitude toward a specific brand in the mind of consumers (William \& Rose, 1990). Brand awareness has a great impact on consumer purchase decision, especially when consumers have lack of knowledge or experience about product quality. Similarly, when consumers have lack of experience with a product, ingredients brand awareness will have a significant impact on their purchasing decisions.

According to signaling theory, the risk-reduction hypothesis suggests that the brand signal is an indicator that reduces the likelihood of a bad outcome for the consumer (Montgomery \& Wernerfelt, 1992). Because the consumer may be uncertain about the quality of unfamiliar brands, signals indicate that specific brands have small variance in their average quality. This minimizes the risk of a bad outcome for the consumer.

A host brand with a perception of poor quality can positively improve consumer perception of the brand as a whole through alliance with an ingredient brand with a strong reputation (Rao et al, 1997). Therefore, it can be expected that the ingredient brand will have a positive effect on attitude toward the host brands.

Based on above theoretical background, we hypothesize as follows:

\section{H1: Ingredient branding is predicted to generate a positive attitude towards the host brand.}

\subsection{Moderating role of regulatory focus}

Consumers' attitudes toward marketing stimuli can be evaluated differently depending on individual motives. According to the self-regulatory focus theory, "people approach pleasure and avoid pain" (Higgins, 1997) which can affect information processing.

To fully understand approach-avoidance motivation, psychologists must go beyond this hedonic principle to the concepts that underlie its many manifestations. Regulatory focus is one such notion, which separates selfregulation with a promotion focus (achievements and ambitions) from self-regulation with a preventive focus (safety and responsibilities).

People interpret information at the concrete level when the preventive focus is more active, whereas they interpret the information at the abstract level when the promotion focus is more active (Lee, Keller, \& Sternthal, 2010). Therefore, when the prevention focus is activated, a more positive evaluation can be obtained when the functional benefit corresponding to the specific attribute of the ingredient brand is sought, whereas when the promotion focus is activated, the symbolic benefit corresponding to the abstract attribute.

It is predicted that more positive evaluation will be obtained when the product is used, and it can be predicted that consumers with an promotion focus rather than a consumption with a prevention focus will actively seek information on the ingredient brand and will clearly recognize the brand awareness.

Based on above theoretical background, we hypothesize as follows:

Hypothesis 2: The influence of ingredient brand awareness on host brand attitudes will be moderated by consumer regulatory focus. More specifically, consumers with a promotion focus more likely to have a positive attitude toward the host brand product than consumers with a preventive focus for the high awareness ingredient brand. 


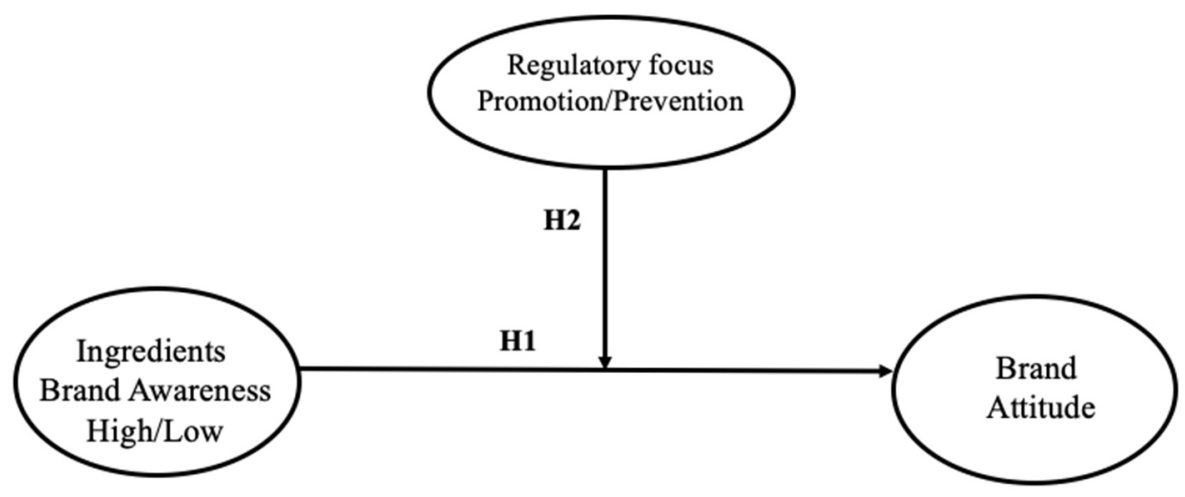

Figure: Research model

\section{RESEARCH METHODOLOGY}

\subsection{Experiment}

In order to investigate the effect of ingredient brand awareness on consumers' attitudes towards the host brands, The current study encompasses the two separate analysis parts. The first part is concerned with high awareness $\mathrm{x}$ 2 (regulatory focus: promotion vs prevention) x 2 (gender: man vs woman) between subject design. Second part is related to the low awareness $\mathrm{x} 2$ (regulatory focus: promotion vs prevention) x 2 (gender: man vs woman) between subject design. A Gore-Tex as a high-awareness ingredient brand, While a Tetratex was presented as a low-awareness ingredient brand.

Therefore, all participants were randomly assigned into one of the four experimental groups. Four types of questionnaire were framed and they differed in ingredient brand awareness manipulation tasks (high and low) and regulatory focus (promotion vs prevention). In order to separate consumers' regulatory focus groups, 18 items referenced in the study were presented so that all types of questionnaires had the same response. These values were classified into an promotion and a prevention focus group based on the mean scores.

Table 1 shows the results of classification into promotion and prevention focus

$<$ Table $1>$ Results of the classification by regulatory focus

\begin{tabular}{|c|c|c|c|}
\hline $\begin{array}{c}\text { Ingredient Brand Awareness } \\
\text { Type }\end{array}$ & Regulatory focus & Gender & Numbers \\
\hline \multirow{6}{*}{ Gore-Tex (high) } & \multirow{3}{*}{ Promotion focus } & Man & 22 \\
\hline & & Woman & 29 \\
\hline & & Total & 51 \\
\hline & \multirow{3}{*}{ Prevention focus } & Man & 31 \\
\hline & & Woman & 24 \\
\hline & & Total & 55 \\
\hline \multirow{6}{*}{ Tetratex (low) } & \multirow{3}{*}{ Promotion focus } & Man & 29 \\
\hline & & Woman & 26 \\
\hline & & Total & 55 \\
\hline & \multirow{3}{*}{ Prevention focus } & Man & 25 \\
\hline & & Woman & 30 \\
\hline & & Total & 55 \\
\hline Total & \multicolumn{3}{|c|}{216} \\
\hline
\end{tabular}

The products we chose for the study are available on the marketplace and according to the previous research, Gore-Tex was a high-awareness brand and Sampatex was a low-awareness brand (Hyeonjeong Jin, Eunyoung Lee, 2007). In above study, Black Yak was selected as the host brand, Gore-Tex was selected as a high-awareness ingredient brand, and Tetratex was selected as a low-awareness ingredient brand.

We used 7-point Likert scale ( $1=$ not at all, $4=$ moderate, $7=$ very much). The results of Gore-Tex and TetraTex were 4.60 and 1.90 and it was confirmed that the awareness of the ingredient brand Gore-Tex was high, and the recognition of Tetra-Tex was low. 
Also, the regulatory focus scale was adapted from Lockwood, Jordan \& Kunda (2002). In order to verify participant's regulatory focus, they were asked a total of 18 regulatory focus scale items, 9 items were related to promotion focus and the remaining 9 items were related to prevention focus. Then we divided the participants into two groups based on mean scores. After that, the median was calculated $(\mathrm{M}=4.538)$, and participants with an score greater than the median were classified as an promotion focus group and those with a small score were classified as a prevention focus group. In this study, prevention-focused items were reverse-coded, and the higher the median score, the higher the promotion focus tendency, and the lower the preventive-focused (Han, 2012). As a result of the reliability test, the Cronbach' $\alpha$ for the promotion focused question was .921 and the Cronbach' $\alpha$ for the prevention-focused question was .946 .

\subsection{Data collection}

The survey was conducted for students of University located in South Korea from April 5 to May 2, 2020. Two hundred and sixteen valid samples were used for the final analysis. All our statistical analyses were done using IBM SPSS Statistics 24.

$<$ Table 2> Demographic profile of respondents

\begin{tabular}{|c|c|c|c|}
\hline & & Number & Percentage $(\%)$ \\
\hline \multirow{2}{*}{ Gender } & Man & 112 & 51.9 \\
\hline & Woman & 104 & 48.1 \\
\hline \multirow{3}{*}{ Age } & Less than 20 years & 22 & 10.2 \\
\hline & $20 \sim 24$ years & 161 & 74.5 \\
\hline & $25 \sim 29$ years & 33 & 15.3 \\
\hline \multirow{6}{*}{ Income } & Less than 2 million & 8 & 3.7 \\
\hline & 20 30 million & 40 & 18.5 \\
\hline & 30 40 million & 72 & 33.3 \\
\hline & $40 \sim 50$ million & 47 & 21.8 \\
\hline & $50 \sim 60$ million & 20 & 9.3 \\
\hline & More than 60 million & 29 & 13.4 \\
\hline \multirow{5}{*}{ Grade } & 1 grade & 24 & 11.1 \\
\hline & 2 grade & 65 & 30.1 \\
\hline & 3 grade & 69 & 31.9 \\
\hline & 4 grade & 57 & 26.4 \\
\hline & Graduate & 1 & 0.5 \\
\hline \multicolumn{2}{|l|}{ Total } & 216 & 100 \\
\hline
\end{tabular}

\section{RESULTS}

\subsection{Reliability and validity of research}

An analysis was performed to verify the reliability and validity of the measured variables of this study. The results are shown in $<$ Table $3>$ below. 
$<$ Table $3>$ Reliability and validity analysis

\begin{tabular}{|c|c|c|c|c|c|}
\hline & Promotion & Prevention & Attitude & Estimate & $\begin{array}{l}\text { Cronbach's } \\
\text { Alpha }\end{array}$ \\
\hline Promo1 & .887 & .014 & .023 & .787 & \multirow{8}{*}{.921} \\
\hline Promo 2 & .884 & .065 & -.008 & .786 & \\
\hline Promo 3 & .869 & .043 & -.009 & .757 & \\
\hline Promo 4 & .821 & -.023 & -.010 & .675 & \\
\hline Promo 5 & .798 & .048 & .025 & .640 & \\
\hline Promo 6 & .770 & .017 & -.008 & .593 & \\
\hline Promo 7 & .709 & -.103 & -.069 & .518 & \\
\hline Promo 8 & .704 & .038 & -.013 & .497 & \\
\hline Preven1 & -.038 & .959 & -.070 & .927 & \multirow{5}{*}{.946} \\
\hline Preven 2 & .013 & .938 & -.084 & .886 & \\
\hline Preven 3 & -.006 & .917 & -.085 & .848 & \\
\hline Preven 4 & .049 & .873 & -.068 & .769 & \\
\hline Preven 5 & .048 & .831 & -.042 & .694 & \\
\hline Attit 1 & .019 & .000 & .850 & .722 & \multirow{6}{*}{.896} \\
\hline Attit 2 & .009 & .067 & .845 & .719 & \\
\hline Attit 3 & -.071 & -.113 & .812 & .677 & \\
\hline Attit 4 & -.025 & -.097 & .798 & .648 & \\
\hline Attit 5 & .016 & -.046 & .785 & .618 & \\
\hline Attit 6 & -.013 & -.165 & .777 & .631 & \\
\hline
\end{tabular}

\begin{tabular}{l|l|l|l|l|l}
\hline Eigenvalue & 5.237 & 4.170 & 3.985 & & \\
\hline $\begin{array}{l}\text { Variance } \\
(\%)\end{array}$ & $27.563 \%$ & $21.948 \%$ & $20.972 \%$ & & \\
\hline $\begin{array}{l}\text { Cumulative } \\
\text { variance (\%) }\end{array}$ & $27.563 \%$ & $49.511 \%$ & $70.483 \%$ & & \\
\hline
\end{tabular}

In order to verify the validity of the measurement items, primary and secondary exploratory factor analysis were performed, and as a result, the total variance of the extracted factors was found $70.483 \%$. In addition, as a result of the reliability analysis on promotion focus, prevention focus, and product attitude, Cronbach's Alpha coefficient was high as .896 .946. This means the principal component analysis is appropriate for this data.

\subsection{The Impact of Ingredient Brand Awareness on Brand Attitudes}

In this study, t-test, two-way ANOVA and three-way ANOVA were used for hypothesis testing. Through this, the difference in attitudes toward the host brand according to the ingredient brand awareness (high/low), and the regulatory focus (promotion /prevention) and gender were examined.

$\mathrm{H} 1$ is to confirm the effect of consumer awareness (high awareness/low awareness) of ingredient brands on consumer attitudes toward host brand. Based on results, consumers showed a more positive attitude toward the host brand when the ingredient brand awareness was high than low ( $\mathrm{M}$ high awareness $=4.95>\mathrm{M}$ low awareness $=4.47$ ), therefore, $\mathrm{H} 1$ was supported.

$<$ Table $4>$ Effect of ingredient brand awareness on brand attitude

\begin{tabular}{|c|c|c|c|c|c|}
\hline & $\begin{array}{l}\text { Ingredient brand } \\
\text { awareness }\end{array}$ & number & mean & t-value & $\begin{array}{l}\text { degree of } \\
\text { freedom }\end{array}$ \\
\hline \multirow{2}{*}{$\begin{array}{l}\text { Host brand } \\
\text { attitude }\end{array}$} & Higher & 106 & $\begin{array}{l}4.95 \\
(.83) \\
\end{array}$ & \multirow{2}{*}{$\begin{array}{c}4.103 \\
(0.001)\end{array}$} & \multirow{2}{*}{214} \\
\hline & Lower & 110 & $\begin{array}{l}4.47 \\
(.89)\end{array}$ & & \\
\hline
\end{tabular}


5.3 The effect of ingredient brand awareness and regulatory focus on attitudes towards host brand products $<$ Hypothesis $2>$ is to verify the moderating effect of regulatory focus (improvement focus/prevention focus) in the relationship between ingredient brand awareness and attitude toward the host brand products. Two-way ANOVA was conducted with the ingredient brand awareness (high awareness/low awareness) and regulatory focus (improvement focus/prevention focus) as independent variables and attitude toward the host brand products as dependent variables. The analysis result is shown in $<$ Table $5>$.

$<$ Table 5> Effect of ingredient brand awareness and regulatory focus on host brand product attitudes $(\mathrm{n}=216)$

\begin{tabular}{c|c|c|c|c}
\hline & Degree of freedom & Mean square & F & sig \\
\hline \hline Ingredient brand awareness (A) & 1 & .896 & 21.027 & $.000^{* *}$ \\
\hline Regulatory focus (B) & 1 & 2.673 & 12.597 & .265 \\
\hline $\mathrm{A} * \mathrm{~B}$ & 1 & 1.474 & 4.803 & $.010^{* *}$ \\
\hline Errors & 212 & .719 & & \\
\hline \multicolumn{4}{|c}{$* \mathrm{p}<.10, * * \mathrm{p}<.05, * * *: \mathrm{p}<.01$}
\end{tabular}

As a result of the analysis, the interaction effect of ingredient brand awareness (high awareness/low awareness) and regulatory focus (promotion/prevention) was significant, therefore, $\mathrm{H} 2$ was supported.

On the other hand, we compared the differences in the attitudes of the host brand products according to the ingredients brand awareness (high /low), focusing on the consumers' regulatory focus (promotion/prevention) tendency. In the case of promotion focus tendency, it was found that when the ingredient brand awareness was higher than when the brand awareness was low, it had a positive effect on the attitude of the main brand product, showing a statistically significant difference $(\mathrm{M}$ high awareness $=5.04, \mathrm{SD}=.800 \mathrm{vs}$. $\mathrm{M}$ low awareness $=4.26$, $\mathrm{SD}=.921 ; \mathrm{t}=4.649, \mathrm{p}=.000)$.

On the other hand, in the case of the prevention focus, the difference in the attitude of the host brand product according to the high and low brand awareness of ingredients was not statistically significant (M high awareness $=4.87, \mathrm{SD}=.848$ vs. $\mathrm{M}$ low awareness $=4.68, \mathrm{SD}=.813 ; \mathrm{t}=1.167, \mathrm{p}=.246$ ).

Figure 2. Changes in Attitude according to Regulatory Focus

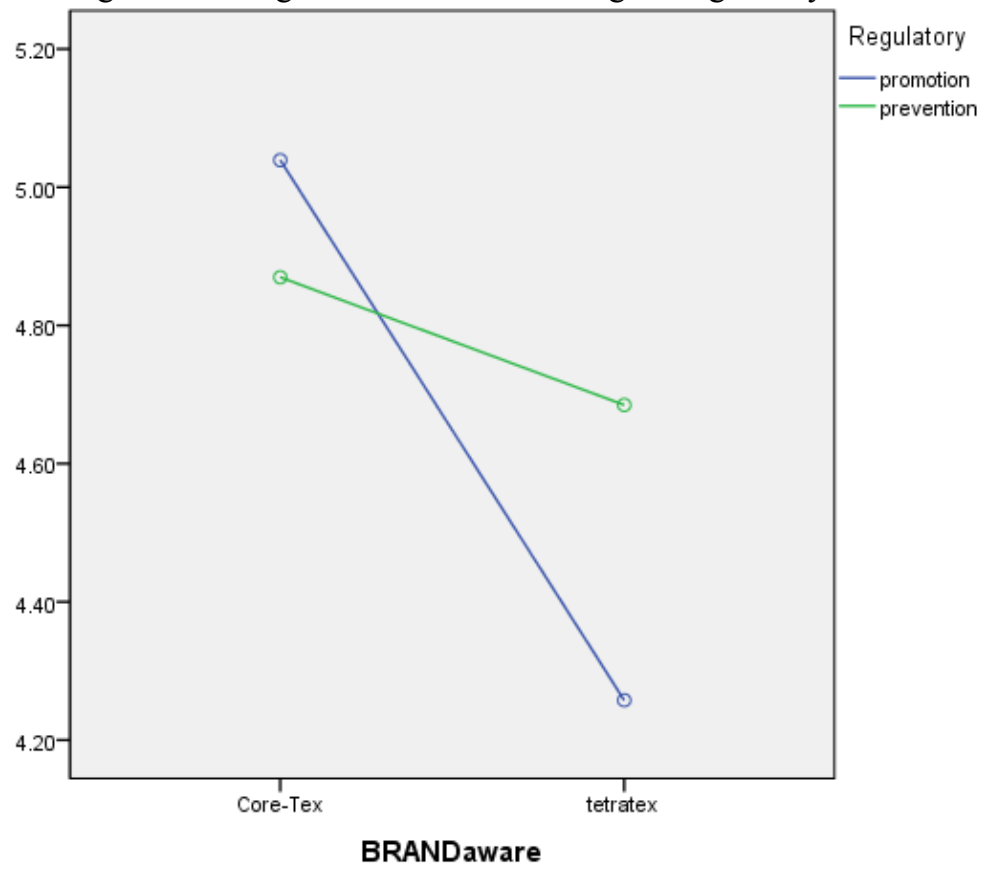

The main effect on ingredient brand awareness (high awareness/low awareness) was found to be significant. Although, the moderating effect between the ingredient brand awareness (high awareness/low awareness) and the regulatory focus (promotion/prevention) and the moderating effect between the variables were significant. This result indicates that the product attitude toward the host brand is higher when the ingredient brand awareness is higher than lower, and that the influence of the ingredient brand awareness on the host brand product attitude can be modulated by the regulatory focus (promotion/prevention).

\section{DISCUSSION}

This study was to examine the effect of ingredient brand awareness on the consumers' evaluation of host brands 
and we also specifically test the moderating effects of the regulatory focus (promotion/prevention) and construal level (higher/lower) in messages. The purpose of this study is to derive theoretical and practical implications for establishing effective marketing strategies to improve corporate performance for companies that launch host brand products using ingredient brands. The results of this study are summarized as follows.

First, As a result of analyzing the effect of ingredient brand awareness on consumer attitude toward the host brand product, it was found that consumers showed a more favorable attitude toward the host brand product when the ingredient brand awareness was high than low.

Second, as a result of examining the moderating effect of consumers' regulatory focus (promotion/prevention) tendency in the relationship between ingredients brand awareness and attitude toward host brand products, the moderating effect of regulatory focus (promotion/prevention) was appeared to be significant.

\subsection{Managerial Implication}

Based on results presented above, theoretical and practical implications of this study were following.

First, it was possible to confirm that the ingredient brands awareness affects consumers' attitudes towards the host brand products. This is an effective strategy for emphasizing the core functions of a product by applying a well-known ingredient brand, which has great implications for companies that want to form a positive attitude toward the host brand. Therefore, companies should recognize the importance of ingredient brand awareness in their host brands and actively promote strategic alliances with companies with high ingredient brand awareness to enhance the competitiveness of their host brand products.

Second, consumers with an promotion focus tend to interpret the utility of product functions more broadly (Zhang et al., 2010). In the case of promotion focus, it was confirmed that the ingredient brand strategy was more effective in the case of the promotion focus. This suggests that the promotion focus is appropriate as a market segmentation for executing the ingredient brand strategy. Therefore, a promotion strategy more emphasis on the ingredient brand is required in a channel that can access consumers with promotion focus, and when the utility of the function corresponding to the ingredient brand can be expressed in concrete and situational positioning, the ingredient brand strategy will be more successful.

\section{REFERENCE}

1. Blackett T., Russell N. (1999) What is Co-Branding?. In: Blackett T., Boad B. (eds) Co-Branding. Palgrave Macmillan, London. https://doi.org/10.1057/9780230599673_1

2. Cegarra, J. J. and Michel, G. (2000), 'Co-branding : clarification du concept et proposition d'un modèle d'évaluation'.

3. Chernev, A. (2004), "Goal-Attribute Compatibility in Consumer Choice," Journal of Consumer Psychology, $14(1 / 2), 141 \sim 50$.

4. Crowe, E. and Higgins, E. T. (1997), "Regulatory Focus and Strategic Inclinations: Promotion and Prevention in Decision-Making," Organizational Behavior and Human Decision Processes, 69(2), 117 132.

5. Dahee Song, (2017), "A study on the effect of presentation color, Construal level, and Regulatory focus on consumers' price perceptions," Ewha Womans University.

6. Desai, K. K. and Keller, K. L. (2002), 'The Effects of Ingredient Branding Strategies on Host Brand Extendibility', Journal of Marketing, Volume 66, January, pp. 73-93.

7. Fishbein, M. and Ajzen, I. (1975), "Belief, Attitude, Intention and Behavior: An Introduction to Theory and Research," Addison-Wesley Publishing Company.

8. Förster, J., Higgins, E. T. and Bianco, A. T. (2003), "Speed/Accuracy Decisions in Task Performance: Builtin Trade-off or Separate Strategic Concerns?," Organizational Behavior and Human Decision Processes, 90(1), 148 164.

9. Janiszewski, C., and Van Osselaer, S. M. J. (2000). A connectionist model of brand-quality associations. Journal of Marketing Research, 37(3), 331-350.

10. Higgins, E. T. (1997), "Beyond Pleasure and Pain,” American Psychologist, 52, 1280-1300.

11. Higgins, E. T. (2002), "How Self-Regulation Creates Distinct Values: The Case of Promotion and Prevention Decision Making,” Journal of Consumer Psychology, 12(3), 177 191.

12. Hyeonjeong Jin, Eunyoung Lee, (2007). "Apparel brand and material brand evaluation according to outdoor sportswear consumers' leisure involvement and product knowledge", Journal of the Korean Society of Clothing and Textiles, 31(9/10), pp.1333 1341.

13. Keller, K.L. (1993), “Conceptualizing, measuring, and managing customer-based brand equity”, Journal of Marketing, Vol. 57, pp. 1-22.

14. Keller, K.L. (2002), "Strategic Brand Management: Building, Measuring and Managing Brand Equity,” NJ: Prentice Hall.

15. Keller, K. L. (2008), "Strategic Branding Management: Building, Measuring, and Managing Brand Equity," Upper Saddle River, New Jersey 07458: Prentice Hall. 
16. Kotler, P. Bowen, J. T. and Makens, J. C., (1999) “Marketing for Hospitality and Tourism,” NJ: Prentice Hall.

17. Kwang-Ho Ahn, 2012; "Moderating Role of Product Tangibility and Customer Type in Brand-Customer Relationship," Advertising Studies 23(2):7-30.

18. Janiszewski, Chris and Stijn M. J. van Osselaer (2000), “A Connectionist Model of Brand-Quality Associations," Journal of Marketing Research, 37 (August), 331-350.

19. Jeon, J. E. and Lee, J. (2016), "Brand Schematicity Moderates the Effect of Aesthetic Brands on Brand Accessories Purchase Intentions," Social Behavior and Personality, 44(10), 1733-1746.

20. Jun-Sang Yeo, (2010), "Effects of Regulatory Focus, Difficulty of Making Extension, and Parent-Extension Similarity on Brand Extension Evaluation," The Korean Journal of Consumer and Advertising Psychology.

21. Lee, A. Y., Keller, P. and Sternthal, B. (2010), "Value from Regulatory Construal Fit," Journal of Consumer Research, 36, 735-747.

22. Levin, A. M., Davis, J. C. and Levin, I. (1996), “Theoretical and Empirical Linkages Between Consumers' Responses to Different Branding Strategies," Advances in Consumer Research, 23(1), 296-300.

23. Liberman, N. and Trope, Y. (1998), "The Role of Feasibility and Desirability Considerations in Near and Distant Future Decisions: A Test of Temporal Construal Theory," Journal of Personality and Social Psychology, 75(1), 5 18.

24. Lockwood, P., Jordan, C. H. and Kunda, Z. (2002), "Motivation by Positive or Negative Role Models: Regulatory Focus Determines Who will Best Inspire Us," Journal of Personality and Social Psychology, 83, 854-864.

25. Marc, Smit(1999), "Ingredient Branding," Co-Branding, 66 83.

26. McCarthy, M. S., and Norris, D. G. (1999), "Improving Competitive Position Using Branded Ingredients," Journal of Product \& Brand Management, 8(4), 267 285.

27. Montgomery, C. A., and Wernerfelt, B. (1988), Diversification, Ricardian rents, and Tobin's q. Rand Journal of Economics 19 (Winter): 623-32.

28. Park, S. Y. and Morton, C. (2013), "The Role of Regulatory Focus, Social Distance, and Involvement in Anti High-Risk Drinking Ad Framing: A Construal Level Perspective," Proceedings of the Conference- American Academy of Advertising.

29. Park, C. Whan, Sung Youl Jun, and Alan D. Shocker (1996), "Composite Branding Alliances: An Investigation of Extension and Feedback Effects," Journal of Marketing Research, 33 (November), 453-66.

30. Rajiv, V. and Praveen, A. (2000), "Strategic Brand Alliances: Implications of Ingredient Branding for National and Private Label Brands," Journal of Product \& Brand Management, 9(4), 214 228.

31. Rao, A. R. and Ruekert, R. W. (1994), "Brand Alliances as Signals of Product Quality," Sloan Management Review, 36(1), 87 97.

32. Rao, K. S., Reddy, M. R., and Reddy, G. V. N. (1997), "Utilization of Sunflower Straw in Complete Diets of Crossbred Bulls,” Indian J. Anim. Nutr., 14(2), 123-127.

33. Simonin, B. L. and Ruth J. A. (1998), "Is a Company Known by the Company It Keeps? Assessing the Spillover Effects of Brand Alliances on Consumer Brand Attitudes," Journal of Marketing Research, 35, 3042.

34. Suh, (2011), "The Moderating Effect of Perceived Values on The Luxury Brand Preference Depending on Consumers' Regulatory Focus" 30(4),73-92, Management and Information Systems Review.

35. Trope, Y. and Liberman, N. (2003), “Temporal Construal,” Psychological Review, 110(3), 403-421.

36. Trope, Y., Liberman, N. and Wakslak, C. (2007), "Construal Levels and Psychological Distance: Effects on Representation, Prediction, Evaluation, and Behavior," Journal of Consumer Psychology, 17(2), 83 95.

37. Washburn, J. H., Brian D. T., and Randi P. (2000), “Co - Branding: Brand Equity and Trial Effects,” Journal of Consumer Marketing, 17(7), 591 604.

38. William, O. B. and Rose, R. L. (1990), "Attention to Social Comparison Information: An Individual Difference Factor Affecting Consumer Conformity," Journal of Consumer Research, 16(4), 461 471.

39. Wilkie, W.L. (1986), Consumer Research, Wiley, New York, NY.

40. Zhang, J.Q., Craciun, G. and Shin, D. (2010), "When does electronic word-of-mouth matter? A study of consumer product reviews", Journal of Business Research, Vol. 63 No. 12, pp. 1336-1341. 